\title{
Common External Tariffs and Trade Efficiency: Lessons for Cross-listed Firms in the East African Community
}

\author{
Abwao Geofrey Magani \\ Department of Commerce and Economics, School of Business, Jomo Kenyatta University of Agriculture \& Technology, Nairobi, Kenya \\ Email address: \\ maganigeofrey@gmail.com

\section{To cite this article:} \\ Abwao Geofrey Magani. Common External Tariffs and Trade Efficiency: Lessons for Cross-listed Firms in the East African Community. \\ International and Public Affairs. Vol. 3, No. 2, 2019, pp. 43-51. doi: 10.11648/j.ipa.20190302.12
}

Received: July 1, 2019; Accepted: August 7, 2019; Published: September 4, 2019

\begin{abstract}
The East African Community's trading bloc has attracted a lot of investment from the member countries yet it has not lived to its expectations. Some of the region's members have fallen out in the past and even re-considered their membership in EAC. Among other areas of focus on the region's integration is the implementation of common external tariffs and protection of the region's members in regional and global market spheres. However, trade efficiency still lags behind in the region compared to global benchmarks. There exists flimsy evidence in literature on whether the implementation of common external tariffs revitalizes trade efficiency in the region. This paper, therefore, propounds the relationship between the implementation of common external tariffs and cross-border trade efficiency within the EAC considering experiences from other regional blocs and the implications for cross-listed Kenyan firms. The paper analyzes secondary data for Kenyan imports and exports from World Integrated Trade Solution (WITS) and the Observatory of Economic Complexity (OEC) as well as Economic review reports from the World Bank, the African Development Bank (AfDB) and EAC. The analysis covering the financial years: 1995 to 2017 shows a number of factors, other than tariffs, that drive trade and trade efficiency. The study also reveals non-tariff barriers, inward-looking trade policies, protectionist policies, redundant trading rules across border, increasing cost of trading among other shortcomings to regional trade that arise from implementation of common external tariffs. Statistical evidence also indicate that trade efficiency is independent of the implementation of common external tariffs. In addition, empirical evidence shows prolonged trade deficit not only in the developed countries, but in the developing world as well. The study concludes that tariffs are good for trade regulation to the detriment cross-border trading even beyond the regional bloc. However, besides macroeconomic correlates, factors other than common external tariffs influence regional and cross-border trade efficiency. This calls for comprehensive in-region trade policy review, revitalization and commitment by the member states even as individual trading entities pursue advanced competitiveness in the regional and global markets.
\end{abstract}

Keywords: Common External Tariffs, Cross-Listing, Cross-Border Trading Efficiency

\section{Introduction}

\subsection{Background to the Study}

International trade and regional integration have gained prominence in modern day business environment as powerful engines for economic and social growth and development. The rationale for international trade and regional integration are well documented and acknowledged in vast literature. Whereas international trade is considered a powerful source of economic, technological and societal change, it is not always rosy as trade can sometimes be disruptive and costly to some regions and countries. Economies in both developed and developing regions undertake regional integration policies and activities in pursuit of common economic, social and political development. This happens against the backdrop of globalization which is occasioned by advances in Information and Communication Technology (ICT). In spite of the world's globalization aspirations and activities, regionalism has occupied the center stage as it shapes economic and political relationships which, in effect, influence multilateral trading patterns and systems. Globally, regional integration is seeks to address political interests which have economic payoffs, in which case, any adverse consequences result from side-effects of political payoff. Various regions in the global economy have organized 
themselves into regional trading blocs some of which have thrived and outlived cross-border challenges associated with regionalism while many others especially in the developing world still struggle to realize objectives such as enhanced bargaining power, advancement of influential social, political and economic lobbies. A remarkable trading bloc in the developed world is the European Union (EU) which has catalyzed economic and political development in Europe. In addition, North American Free Trade Agreement (NAFTA) was formed by Canada, Mexico and the United States of America as Singapore and Japan signed a trade accord. Other prominent regional blocs include Association of South East Nations (ASEAN), Free Trade Area of the Americas (FTAA), Asia Pacific Economic Cooperation (APEC), Caribbean Common Market (CARICOM) and MERCOSUR in which Paraguay, Brazil, Argentina and Uruguay are members.

Regional trade agreements have lately been at the center of many policy debates which are aimed at shaping and sustaining trade and economic relations world over. In fact, formation of new trade agreements is expected as negotiations and discussions are in progress. Such developments from developed regions include Brexit and NAFTA which focused on reversing or renegotiating ongoing trade arrangements. Besides, other developing regional outfits include Comprehensive and Progressive Agreement for Trans-Pacific Partnership (CPTPP), USMCA, the European Union-Mercosur Trade Agreement and Africa's Continental Free Trade Area (CFTA) [37]. In the African context, There is adequate evidence in support of Africa's concerted efforts towards regional integration [25, 32]. The African ccountries have been keen on driving their development agenda through regional collaborations through such regional organizations as the East African Community (EAC), Southern African Development Community (SADC), Common Market for Eastern and Southern Africa (COMESA), East African Community (EAC), Economic Community for West African States (ECOWAS).

To implement its regional development agenda, in particular, the East African Community (EAC) member states have made efforts to deepen regional integration and inregion trade by establishing closer economic links through a Free Trade Area (FTA), a Customs Union (CU), a Common Market (CM), a Monetary Union (MU) and development of a Political Federation (PF). The EAC was established in July, 2000 by three partner states including Kenya, Uganda and Tanzania who were later on joined by Rwanda and Burundi in 2007 and later South Sudan joined the community in 2016 in pursuit of widening and deepening intra-regional cooperation and trade liberalization. The purpose of the said liberalization was to ease free movement of factors of production majorly to widen and deepen the levels of economic and social cooperation among the member states. The socio-political and economic integration initiatives are aimed at creating an enabling trading environment for enterprises in the wider regional market. However, regional integration faces a number of economic, political and social dynamics which present opportunities and threats to enterprises from the member states of the trading bloc.

The EAC is the fastest growing region in Africa [36] with a market size of about 146 million in-region consumers. The members to the community have undertaken various measures to enhance intra-region trade including; the digning of customs union protocol; common market protocol; trade and investment framework agreements; policy development on competition and enforcement of anti-dumping regulations; and trade facilitation through simplification, standardization and harmonization of trade information and documentation. However, there are times when international and in-region trading activities prove either uneconomical or sometimes become unsustainable especially to developing and less developed economies as a result of inward-looking trade policies, protectionist policies, over-valuation of exchange rates, inflation and low growth of exports thereby constraining efficient trading in local and emerging foreign markets [25]. It is upon this realization that nations pursue market integration, trade liberalization and development of export oriented trade policies for mutual benefits to the member states. According to the study [32] the formation of East African Community's Common Market presents myriad opportunities for enhancing the competitiveness of enterprises from member states as well as their comparative advantage against the global competition. The degree of market integration is critical for diversification, financing decisions, risk management and peace-building among the member states. It also enhances interdependence, cooperation and regional bargaining power in the course of market expansion.

Regional integration efforts do not merely enhance competition, but competitiveness of the trading bloc as well as the member states' individual competitiveness in the global markets. Market integration efforts ease cross-border trade barriers and lead to the convergence towards a monopolistic competitive market structure [35]. The advances made towards the integration of EAC member states into a formidable trading bloc sought to address the social, political and economic deficiencies of the individual member countries. A number of legislations, treaties and binding cooperation agreements have been established to strengthen the region's trading bloc [10] However, extant literature point to various dynamics which include: significant tax pressures, administrative barriers, technical regulation, unstable political situations, heterogeneous monetary policy environments, fiscal variations as well as fiscal shocks - all which derail the entrepreneurial efforts and initiatives of the member countries $[6,14,35,17]$.

\subsection{Statement of the Problem}

The EAC was formed to improve the social, political and economic development of the member states and to protect the interests of the region. The purpose of the regional trading bloc is to establish a common market, a monetary union and customs union and a free trade area. The EAC economies thus came together to pursue East African market integration, trade liberalization and development of export 
oriented trade policies for mutual benefits to the member states. The member states have established common external tariffs to protect a single custom territory, enjoy economies of scale and enhance the region's competitiveness and performance in the global market. However, the EAC efforts have been curtailed by a number of regional challenges and predicaments thereby impacting the pursuit of EAC market objectives. For example, a fall-out of the EAC member states on unequal sharing of benefits and deficiency of political goodwill among leaders ushered in the EAC's collapse in 1977[32]. Following the re-establishment of the EAC in 2000 and the subsequent signing of EAC customs union protocol, EAC Common Market protocol and the EAC Monetary Union protocol among other agreements, there have been a lot of expectations for a more united, integrated and liberalized bloc yet implementation remains a concern for inregion trade. The implementation of CETs has not been spared either going by low intra-Africa trade estimate of $14 \%$ [36]. Whereas the EAC business environment is presumably better than other regions in Sub-Saharan Africa as pointed out in African Development Bank Group's [36] east Africa regional strategy paper 2018-2022, the bloc lags behind various developing regions. Despite the developing countries in the EAC having registered improved economic growth rates, the annual economic growth averages per country and the region as a whole still fall short of the $8.5 \%$ growth threshold necessary for the region to advance to upper middle-income status. According to the said strategy paper, the EAC region is ranked 110th out of 190 in terms of business environment considering a number of cross-border factors inhibiting trade efficiency. Inward-looking trade policies, protectionist policies, pervasive infrastructure gaps, inadequate regional policies and frameworks, over-valuation of exchange rates, inflation and low growth of exports $[32,6]$ have constrained the region's traders' from meeting the requirements of current and emerging foreign markets [25] inspite of implementing the CETs. As a result, there arises a concern as to whether the EAC aspirations on implementation of CETs have actually enhanced trade efficiency across the region's borders. Besides, there is flimsy evidence in literature on whether the implementation of common external tariffs revitalizes trade efficiency in the region. It is on these grounds that the paper sought to propound the relationship between the implementation of common external tariffs and cross-border trade efficiency within the EAC considering experiences from other regional blocs.

\subsection{Objective of the Study}

To examine the influence of adoption of common external tariffs on trade efficiency and hence propound some lessons for cross-listed firms in the East African Community.

\subsection{Scope of the Study}

This study involved content analysis of regional trade, an analysis of secondary data for Kenyan imports and exports from World Integrated Trade Solution (WITS) and the Observatory of Economic Complexity (OEC). Other supplemental sources of information included Economic review reports from the World Bank, the African Development Bank (AfDB) and EAC. The study lasted over a six month period beginning from February to July, 2019 and covered the financial years: 1995 to 2017 . For crosslisted firms and other entities involved in cross-border trading within the region, a number of factors attributed to market inefficiency that have a stint on the trade facilitation efforts. Some of the cross-listed entities in East Africa include Nation Media Group, Centum Investment Company Ltd, East African Breweries Ltd, Equity Bank, Kenya Airways, Jubilee Holdings Ltd, Umeme Ltd, Kenya Commercial Bank, Bank of Kigali and Uchumi supermarkets. This review exemplifies extant in-region trade pressures that inhibit trade facilitation in spite of the regional bloc agreements.

\subsection{Significance of the Study}

This study provided important trade facilitation information for informed investment and trading decisions with relevance to cross-border traders operating within the EAC bloc, companies that are cross-listed on NSE and other EAC bourses. The review also unearthed the progress, fears and implications of the EAC regional trade facilitation occasioned by introduction of CETs. Market participants in the EAC bourses also gain current insights from the study findings upon which informed decisions and market activities can be undertaken. The EAC integration organs can also gain an understanding of the current scenarios in the region's capital markets to guide forward planning and action as the drive to establishing a formidable EAC trading bloc advances. Among other beneficiaries are commodity traders involved in importation and exportation of merchandise across the EAC borders as well as those trading with other regions and international markets in Africa and other continental markets. The study findings also inform policy development and implementation at company, government and regional levels. Importantly, the study contributes to a body of literature in finance, regional markets and regional development.

\section{Literature Review}

\subsection{Theoretical Review}

\section{Efficient Market Hypothesis}

This study is anchored in the Efficient Market Hypothesis (EMH) theory which was developed by Eugiene Fama. The theory avers that in efficient markets, a large number of rational profit maximisers actively compete and the actual market prices reflect information on events that have occurred and those events that are expected to occur. According to the proponent of the EMH theory, a market is efficient if the prices always fully reflect available information which is almost freely available to all 
participants. This implies that public and privately held information is available for use by traders, investors and other market participants in evaluating prices, determining commodity values, and trade executing in the market. Market efficiency takes different forms: the weak form of EMH, semi-strong form of EMH and strong form of EMH. The weak-form of EMH assumes that historical price information is instantaneously incorporated into prices while the semistrong form of EMH assumes that prices reflect all the publicly available information and the strong-form of EMH assumes that besides the historical and publicly available information, private information is also reflected in the prices. There exists a lot of EAC tariff information and interventions that are geared towards facilitating and sustaining efficiency in trading both within the EAC bloc as well as other regional and global markets. Continuous regional integration efforts, activities and interventions on building wider, resilient and efficient in-region and global markets for the EAC members are aimed at facilitating trade and easing the cross-border trading within the EAC. The EMH theory thus applies to the review on the correlates of trade efficiency and facilitation situation occasioned by the adoption of common external tariffs in the East African Community in light of enforcement and utilization of EAC tariffs.

\subsection{Empirical Review}

\subsubsection{Cross-Border Market Efficiency}

The EAC regional integration agenda provides for facilitation of cross-border trade and investment amongst the member states by enabling the exchange and mutual recognition of trade-related data and documents for efficient international trade transactions. Cross-border markets become efficient when the capital market prices correctly utilize all the available information instantaneously. Such information determines the form of market efficiency as defined by Eugiene Fama's Efficient Market Hypothesis (EMH) which are: weak form efficiency, semi-strong form efficiency and strong form efficiency. Empirical evidences show that crosslisted firms benefit from informational efficient pricing, reduced opacity arising from minimized informational asymmetry challenges, enhanced liquidity and visibility, signalling for and low cost of capitalization as well as investment efficiency after cross-listing [1, 28, 19]. Crosslisting an entity helps improve the firm's visibility and enlarges its investor base. However, the advantages of crosslisting may be hard to come by considering exchange rate risks, incompatibility of trading and settlement systems, diverse trading regulations and failure by the issuing companies to increase free float shares in the new markets [3, 28, 23].

\subsubsection{Common External Tariffs}

Evidences from the implementation of common external tariffs in various trading blocs support the restriction of imports, protection of in-region industries, enhancing the attractiveness of local production and relaxed government interference with the private sector. Conversely, research findings show that tariff-based trade restrictions discourage competition which eventually leads to inefficiency of domestic firms and retaliation by other countries from hence impeding imports and exports in the global markets [5]. Evidence from the tariff-based trade wars between the United States of America (USA) and China both targeting industrial parts, furniture, appliances, steel, food textiles, chemical products among others which influence trade and investing decisions. The trade tariffs raise commodity prices, reduce the supply of imports for households and businesses which thereby lowering economic output, the country's GDP and worsens unemployment in the long run [34]. The trade wars do not spare stock markets and securities markets, which have also exhibited varied responses depending on their direct and indirect exposures to the US-China trade strains. The US-China trade tensions occasioned by tariff increments have also lowered the US stock market performance [29]. Figure 1 shows the USX drop against the benchmark index as at 2 ist June 2019 following the presidential pronouncement of $25 \%$ duty on imports up from $10 \%$.

At market close 06/21/2019

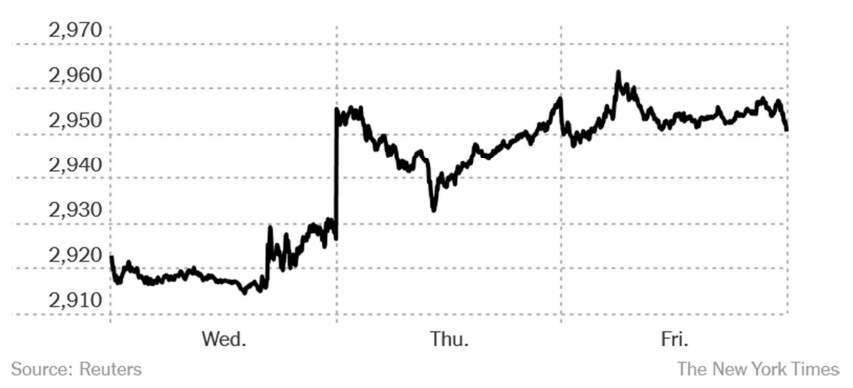

Figure 1. US-China Stock Market Performance.

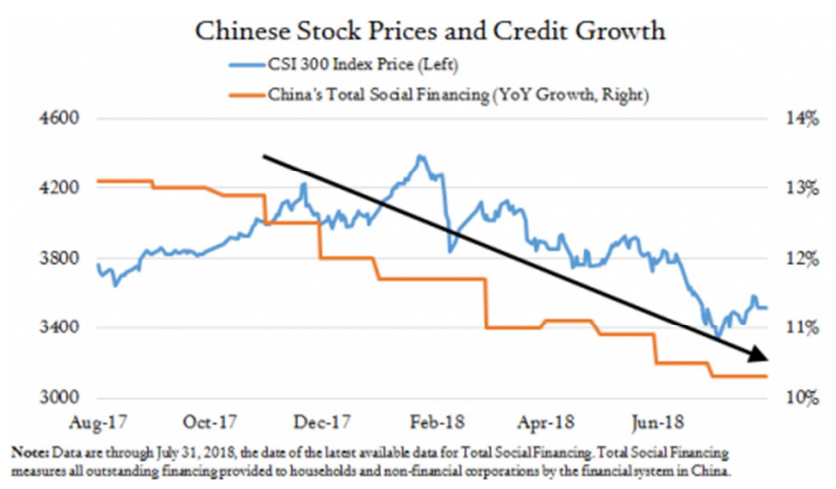

Figure 2. US-China Stock Market Performance.

Empirical evidence [15] from analysis of the trade linkages and firm value based on the indications from the 2018 USChina "Trade War" market responses were evaluated. The evaluation of firms in both countries was hinged on their direct and indirect US-China trade experiences. The stuidy revealed that US firms that rely on China for both importation and exportation had higher default risks coupled with diminished stock and bond returns. [25] The study presents a complex view of global trade from the US-China tradeb tensions whose impact affect many economies directly 
and indirectly. Various studies have also analysed the crossborder trading in developed and emerging markets following the imposition of common external barriers considering the exports and imports, the exports and trends, and major products traded in the regional blocs [5, 7-9, 11-13, 31, 22, $27,32]$. The analyses indicate a discourse in research findings concerning the imposition of tariffs on imports to various regions and countries.

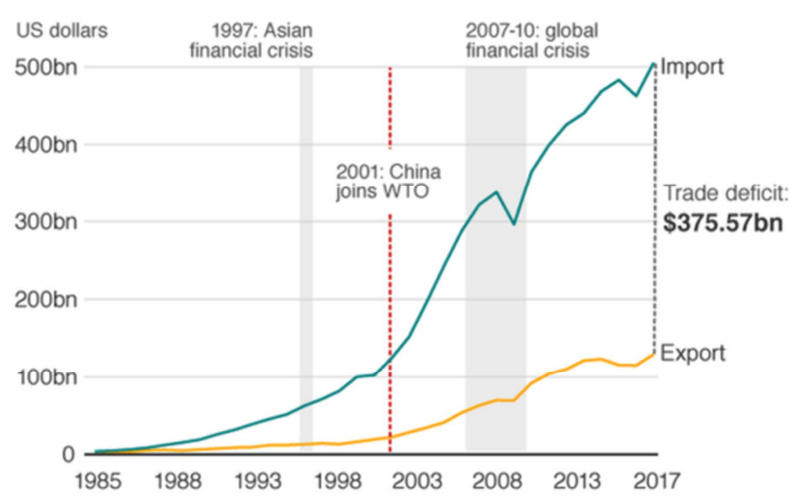

Source: US Census Bureau

BBC

Figure 3. US trade in goods with China.
In Central Europe, seven (7) European countries that are non-European Union members established the Central European Free Trade Agreement (CEFTA) in the year 2006 with the aim of creating a more enabling trading environment for the member states. The CEFTA members who include Serbia, Macedonia, Albania Moldova, Montenegro, Bosnia and Herzegovina entered into a trade deal with the intention of reduce trade tariffs amongst the members of the trading bloc. Despite the successful implementation of zero tariff for trade amongst the member states, trading activities within the CEFTA region still suffer a number of non-tariff barriers including: numerous and redundant trade-related procedures, overlapping data and documentation requirements for firms, excessive inspections across the borders among others. Accordingly, the study [20] analysed the trade effects of Albania's trade agreements with CEFTA members with a focus on the country's exports. The study which used a trade growth decomposition methodology reveals that the agreement opened up the export market for the Albanian entities that did not export to CEFTA members prior to the trade deal. The findings of the study indicate that CEFTA increased the Albanian exports in the range 34\% - 144\%. Figure 4 shows the trends in trade balance between Albania and the world.

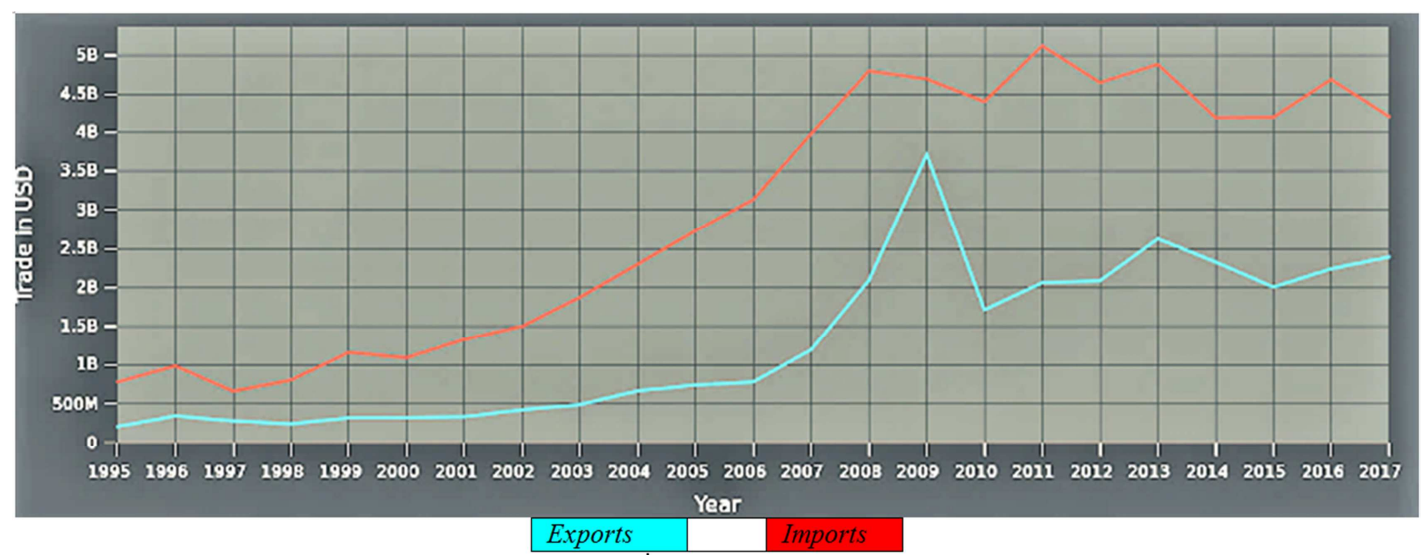

Source: The Observatory of Economic Complexity, 2019.

Figure 4. Albanian Trade Balance.

Whereas the African Development Bank's (2018) perspectives on the African Economic Outlook indicate resilience of the African economies with increased real output generally signalling good macroeconomic policy space, regional integration efforts and progress in structural reforms, earnings from exports still remain a concern for the African countries. For instance, [2] economic outlook shows that the tax revenue collection in Africa increased by $2.3 \%$ in absolute terms in 10 year-period from 2006 to 2016 compared to other continents. The tax revenue increment is attributed to among other categories, higher tax charges on domestic production, incomes and tariffs, some of which can be counterproductive and distortionary.

Despite the need to strengthen the economic resilience of African countries to lift the economies to new growth equilibrium, the economies still need to rethink their bilateral and multilateral regulations for trade facilitation at national, sub-regional and regional levels. The study [22] reviewed the changing landscape of trade facilitation and regional development issues in West Africa in the wake of technological advancements, digital commerce and increased trade integration. The study underscores trade integration and intergovernmental collaboration efforts towards strengthening South-South regional trade partnerships which account for the trade expansion being experienced in Africa. Despite the ongoing African Continental Free Trade Area (AfCFTA) negotiations, the study findings reveal increasing trade costs to sub-regional trading blocs mainly arising from increasing non-tariff measures including: lengthy customs processes, inadequacies of transport, logistics and infrastructure and well as incoherent cross-border trade documentation. 


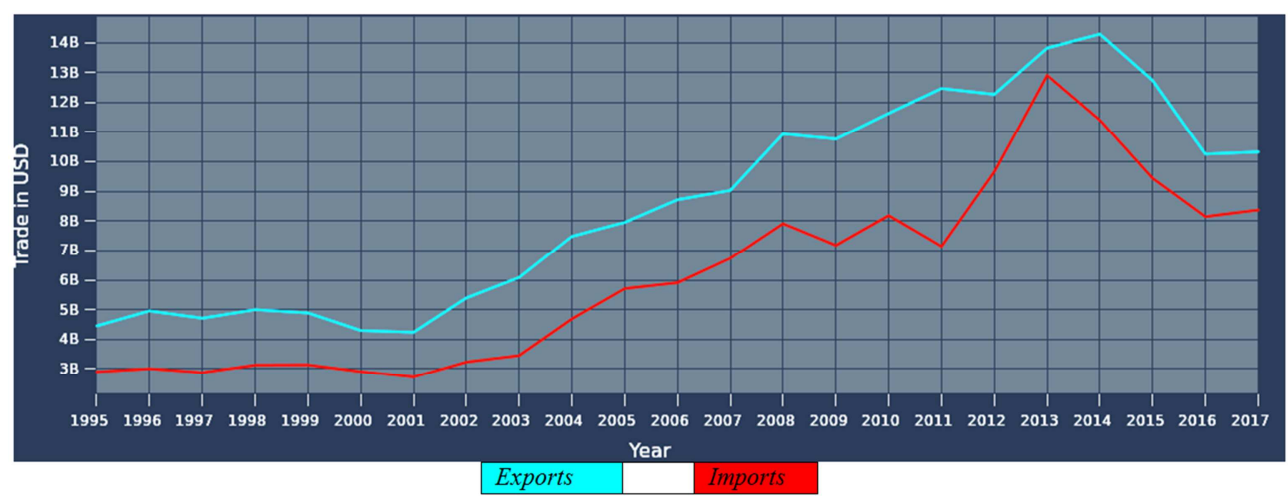

Source: The Observatory of Economic Complexity, 2019.

Figure 5. Cote De'Ivoire's Trade Balance.

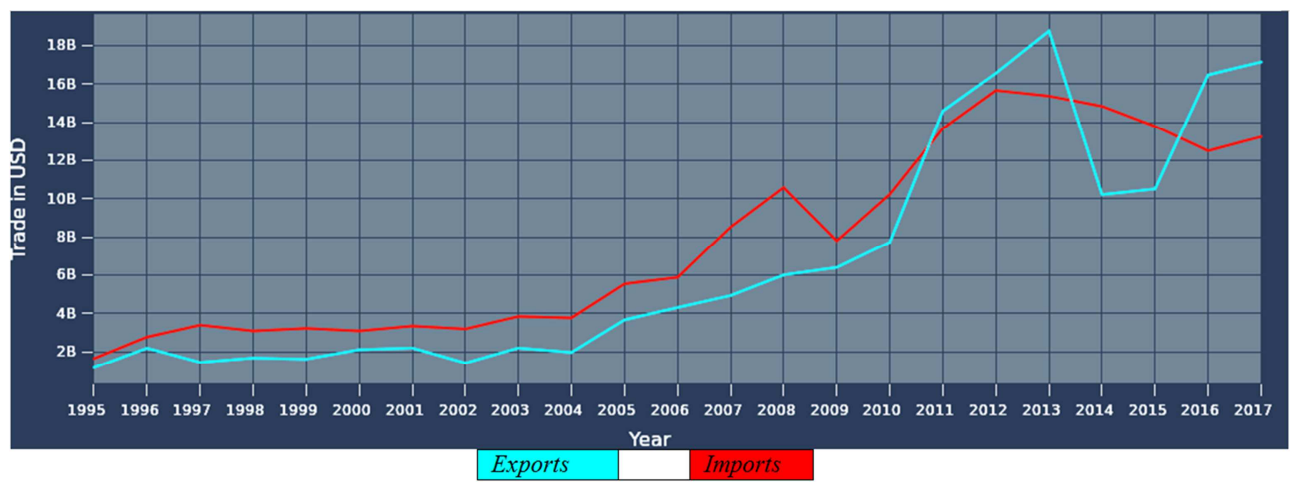

Source: The Observatory of Economic Complexity, 2019.

Figure 6. Ghanaian Trade Balance.

Empirical studies and analyses from developed economies also associate deficiencies in both bilateral and multilateral trade to factors including unfavourable customs entry procedures, stringent administrative entry procedures, technical barriers to trade, costs involved in accessing traderelated services among others. Besides the common external tariffs imposed by regional trading blocs, various shortcomings of existing and emerging regional and subregional free trade agreements have causal relationships with some new economic structure changes in the contemporary globalization and regionalization discourse. These shortcomings concur with the paper [9] analysis of the perspective of the future of free trade agreements and their potential shortcomings from Singapore's experiences. The study recommends more comprehensive free trade agreements that can: eliminate non-tariff barriers and eliminate potential barriers; enhance intellectual property protection; manage trade and FDI policies and enhance regional and global trade integration in future.

In Africa, regional trading blocs have made concerted efforts towards realization of the continent's trade integration besides strengthening the sub-regional free trade agreements. The study [26] analysed the impact of regional integration among countries from the Common Market of Eastern and Southern Africa (COMESA) -EAC-Southern African Development Community (SADC) tripartite free trade agreement which was established in 2011. The analysis used an extended gravity model on a panel of 51 African countries using data for 15 years from 1995 to 2010. The study particularly analysed average tariff data on global imports and the findings revealed negative correlation between tariffs and imports as individual countries within the African region seek to protect their respective national interests more than they do with regional trade interests. As the research [18] observe, this scenario is partly because not all African countries within each of the tripartite trading blocs are integrated to their specific regional blocs.

The paper [11] analysed the relationship between trade openness and domestic market share with a focus on the manufacturing firms in Egypt. The study which analysed how manufacturing plants in Egypt respond to changes in trade tariffs used firm-level data and relied on Levinsohn and Petrin (2003) methodology to determine the level of total factor productivity for the sampled Egyptian manufacturing entities. The methodology used allows for the use of a commonly observable variable to control for unobserved productivity based on the assumption of inherent perfect competition. According to the findings of the said study, which is in agreement with heterogeneous business models of international trade, a decline in market concentration and the market share of the firms studied after the trade policy reforms pursued in 2004.

Despite the efforts to enhance trade liberalization, little progress in the fight against corruption as well as a less 
enabling business environment affect business activities in the country $[4,13]$. Though the the research [30] posits that the Egyptian economy has stabilised most recently as the macro-economic and policy reforms have consistently improved the country's external position, parity in trade balance still manifests. There is weak market competition despite remarkable developments in the private sector. The reforms have seen the reduction of tariffs and tariff bands narrowed down only applied to a few commodities and therefore, the tariff reductions have insignificantly translated into increased integration of the Egyptian economy. Figure 7 illustrates the trade patterns after the reforms.

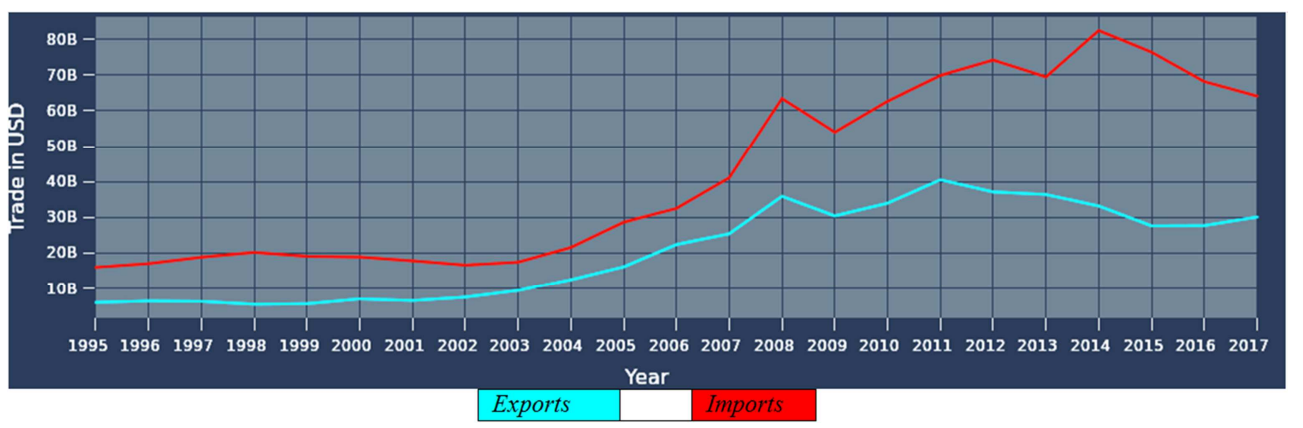

Source: The Observatory of Economic Complexity, 2019.

Figure 7. Egyptian Trade Balance.

Figure 7 shows a deficit in balance of trade alongside the high debt ration standing at $98.7 \%$ of the GDP in financial year 2018 as the current account deficit narrowed.

From the time of inception of the EAC, the in-region trade agreements have not been immune to negative effects of free trade and developments in regional integration. This is evidenced by the low percentage of intra-African trade as a percentage of the total trade relative to other developing regions. Unlike other African regional trading blocs, the EAC partners have made more concerted efforts to harness their economic potential and ease the regional trade burden associated with tariffs, other taxes restrictions and nonconforming measures. However, the East African Common Market Scorecard of 2016 shows that the free movement of capital, services and goods amongst the partners within the EAC region is fraught with challenges. The EAC exports only 20 per cent of its commodities to the EAC market, a phenomenon that brings out acute imbalances in trade in the region resulting from non-tariff barriers to the free flow of capital, goods and services. The EAC member states continue to make progress on eliminating tariffs by partners and non-tariff barriers inhibiting intra-regional trade. This is evident from the information gathered from commercial and investment banks, brokerage houses, central banks, stock exchanges and World Bank Group reports on compliance to the region's Free Trade Agreements [31].

Various empirical analyses have as well been done on the impact of tariffs in Kenya which have elicited critical views on trade, investment, integrated market discourse. According to the paper [16] in their evaluation of the impacts of tariff reduction and mixed fiscal policy on Kenyan agricultural and food industry, economic welfare is enhanced by elimination of trade tariffs. The study used the Macro Computable General Equilibrium Model and assumed close interelation between thecountry's fiscal policy and economic welfare. However, the study findings indicate that the elimination of tariffs enhances economic welfare subject to some optimal government expenditure. The findings further link the improved economic welfare to, among other factors, high consumption in the economy, improved levels of consumer incomes, GDP, increased demand for factor endowments and limited public service expenditure. This implies that a country's economic welfare is dependent on a myriad factors besides elimination of tariffs as a way of trade liberalization.

This argument is asserted by the study [24] review paper which examined the welfare effects of the reciprocal free trade pacts between Sub-Saharan Africa and the industrialized world. Using the General Equilibrium Model framework, the study underscored the inaccurate estimation of trade impacts explained by variances in labour productivity growth rates. The findings concur with the conclusion by the research [16] noting that the elimination of reciprocal tariff with the industrialized world slightly improves trading implying that trade liberalization is not a panacea for economic welfare improvement. Developing countries need to improve their capital productivity, competitiveness and address other non-tariff barriers in order to realize greater benefits of bilateral and multilateral trade. Figure 8 Shows a trend analysis of Kenya's economic welfare over a 14 year period from $2004-2017$ in support of the foregoing discussion. The results shown in Figure 8 indicate that Kenya had a total export of US\$5,747,414,820 and total imports of US\$ $16,690,197,050$ in leading to a negative trade balance of US\$ $-10,942,782,230$. The trade growth is $-3.67 \%$ compared to a world growth of $1.50 \%$. GDP of Kenya is $79,263,075,749.27$ in current US\$. Kenya services export is $4,647,692,401.86$ in BoP, current US \$ and services import is $3,091,958,193.70$ in BoP, current US \$. Kenya exports of goods and services as percentage of GDP is $13.17 \%$ and imports of goods and services as percentage of GDP is $24.08 \%$ (World Bank Group, 2018). 


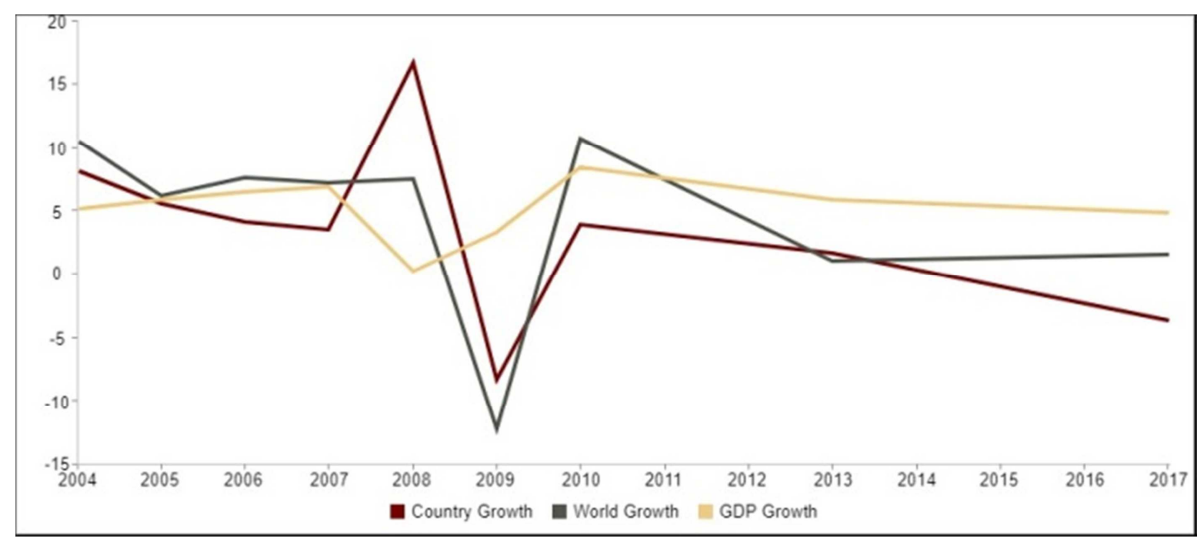

Source: World Integrated Trade Solution (2019).

Figure 8. Kenya Country Growth V/S World Growth V/S GDP Growth.

\section{Conclusion}

Statistical findings from World Integrated Trade Solution (WITS) and the Observatory of Economic Complexity (OEC) as well as Economic review reports from the World Bank, the African Development Bank (AfDB) and EAC are consistent on the trade deficits comparing imports and exports statistics. Both in-country and in-region statistical analysis following the implementation of common external tariffs show low welfare gains from regional integration for countries that do not eliminate non-tariff barriers while countries that reduce non-tariff barriers experience comparatively high welfare gains. Besides, statistical analysis shows prolonged deficits in balance of trade and balance of payments in both developed and developing economies and the EAC is no exception. Trade inefficiencies and market imperfections persist despite numerous market integration and innovation efforts. Non-tariff barriers, inward-looking trade policies, protectionist policies, redundant trading rules across borders, increasing cost of trading among other shortcomings to regional trade still constrain bilateral and multilateral trade in spite of the implementation of common external tariffs in the region. For cross-listed entities, empirical results show inefficiencies in regional trading activities evidenced by prolonged trade deficit in the developed and developing world countries. The study concludes that tariffs are good for trade regulation to the detriment cross-border trading both within and beyond the regional bloc. However, besides macroeconomic correlates, factors other than common external tariffs influence regional and cross-border trade efficiency. From a policy perspective, the imperatives for enhanced trade efficiency in the emerging EAC markets include a comprehensive intra-region trade policy review, revitalization and refocused commitment by the member states towards regional market efficiency through liberalization even as individual trading entities pursue advanced competitiveness in the regional and global markets. Further studies should analyze the macro-economic correlates of CETs in relation to EAC market integration and trade facilitation efforts and the resultant impact on economic growth and development of the region.

\section{References}

[1] Abdalla, A. A., \& Abdalla, W. (2019). Does cross-listing in the US improve investment efficiency? Evidence from UK firms. The Quarterly Review of Economics and Finance, https://doi.org/10.1016/j.qref.2018.12. 005.

[2] African Development Bank Group. (2018). African Economic Outlook 2018. Retrieved June 24, 2019, from African Development Bank Group: https://www.afdb.org/fileadmin/uploads/afdb/Documents/Publ ications/African_Economic_Outlook_2018_-_EN.pdf.

[3] Aladesanmi, O., Casalin, F., \& Metcalf, H. (2019). Stock market integration between the UK and the US: Evidence over eight decades. Global Finance Journal, Vol. 41 (1) pp. $32-43$.

[4] Alissa, S. (2007). The Political Economy of Reform in Egypt: Understanding the Role of Institutions. Carnegie Endowment for International Peace, pp. 1-32.

[5] Avdasheva, S., \& Gimadi, V. (2019). Investor Response to Tariff Options under Regulation by Contract: Evidence from Russian Heating Concessions. Utilities Policy, Vol. 57, April 2019, Pages 64-74.

[6] Battistini, N., Callegari, G., \& Zavalloni, L. (2019). Dynamic fiscal limits and monetary fiscal policy interactions. European Central Bank: Working Paper Series.

[7] Berger, A. N. (2003). The Efficiency effets of a single market for Financial services in Europe. European Journal of Operational Research, vol. 150 (3); pp. 466-481.

[8] Casu, B., \& Girardone, C. (2010). Integration and Efficiency Convergence in EU banking markets. Omega, 38 (5), pp. 260267.

[9] Chen, X. (2019). The Future of Free Trade Agreements: Singapore Perspetive. International Journal of Economic Policy Studies, vol. 13 (1), pp. 259-271.

[10] East African Community. (2000-2019). Overview of the EastAfrican Community. Retrieved April 20th, 2019, from East African Community: https://www.eac.int/overview-ofeac. 
[11] Elewa, A. (2019). Trade Openness and Domestic Market Share: Evidence from Egypt Firm-Level Data. Journal of Industry, Competition and Trade, pp. 1-23.

[12] Erixon, F. (2016). What is Wrong with the Single Market. European Centre for International Political Economy.

[13] Ghoneim, A. (2005). Law-Making for Trade Liberalization and Investment Promotion in Egypt. Cairo University, pp. 1-32.

[14] Holynskyy, Y., \& Onyusheva, I. (2019). Budget and fiscal policies' Modernization as a factor of national competitiveness increase (the case of Ukraine). The EUrASEANs: Journal on Global socio-economic dynamics, vol. 1 (14), pp. 16-29.

[15] Huang, Y., Lin, C., Liu, S., \& Tang, H. (2018). Trade Linkages and Firm Value: Evidence from the 2018 US-China "Trade War". SSRN, Huang, Yi and Lin, Chen and Liu, Sibo and Tang, Heiwai, Trade Linkages and Firm Value: Evidence from the 2018 US-China 'Trade War' (Augushttp://dx.doi.org/10.2139/ssrn.3227972).

[16] Igesa, B. S., Okiyama, M., \& Tokunaga, S. (2018). Impacts of Tariff Reduction and Mixed Fiscal Policy on the Kenyan Agricultural and Food Industry: Using the Macro CGE Model. Jpn. J. Agric. Econ., Vol. 20, pp. S1-56, 2018.

[17] Leeper, E. M., Plante, M., \& Traum, N. . (2010). Dynamics of fiscal financing in the United States. Journal of Econometrics, Elsevier, vol. 156 (2), pp 304-321.

[18] Mabe, Q. M., \& Bonga-Bonga, L. (2019). How Financially Integrated are Trading Blocs in Africa. The Quarterly Review of Economics and Finance, https://doi.org/10.1016/j.qref.2019.05.013.

[19] Makau, S. M., Onyuma, S. O., \& Okumu, A. N. (2015). Impact of Cross-border Listing on Stock Liquidity: Evidence from East African Community. Journal of Finance and Accounting, Vol. 3 (1), pp. 10-18. doi: 10. 11648/j. jfa. 20150301. 12.

[20] Minondo, A., \& Choi, J. (2019). The Trade Effects of Albania's Trade Agreements with CEFTA members. PostCommunist Economies, Vol. 31 (4), pp. 451-463.

[21] Observatory of Economic Complexity. (2019). OEC. Retrieved June 20, 2019, from OEC: https://atlas.media.mit.edu/en/profile/country/egy/.

[22] Odularu, G. (2019). Introduction: The Changing Landscape of Trade Facilitation and Regional Development Issues in West Africa. In A. P. Odularu G., Trade Facilitation Capacity Needs (pp. pp. 1-23). Palgrave Pivot, Cham.

[23] Onyuma, S. O., Mugo, R. K., \& Karuiya, J. K. (2012 ). Does Cross-Border Listing (STILL) Improve Firm Financial Performancein Eastern Africa? Journal of Business, Economics \& Finance, Vol. 1 (1) pp. 92-109.

[24] Rakotoarisoa, M. A., Khorana, s., \& Narayanan, B. G. (2019). Trade Liberalization - Labour Productivity Nexus: The Case of Subsaharan Africa. Socio-Economic Challenges, Vol. 3 (1), pp. 5-26.

[25] Rwehumbiza, D. A. (2010). The East African Community
(EAC) and its Influence on Tanzania's Manufactured Exports Intensity and Competitiveness. Business Management Review, vol. 14 , pp. $58-82$.

[26] Slany, a., \& Riedel, J. (2019). The potential of African trade Integration - Panel data evidence for the COMESA-EACSADC Tripartite. The Journal of International Trade and Economic Development, DOI: 10. 1080/09638199. 2019. 1575457.

[27] Tang, D. (2019). Has European monetary union influenced the European Union bank lending flows to the EU countries from Central and Eastern Europe? Journal of Financial Economic Policy, Vol. 11 Issue: 2, pp. 263-282, https://doi org/10.1108/JFEP-05-2018-0080.

[28] Temouri, Y., Driffield, N., \& Bhaumik, S. K. (2016). A strategic perspetive of cross-listing by emerging market firms: Evidence from Indonesia, Mexico, Poland and South Africa. Journal of International Management, vol. 22 (2016), pp. 265-279.

[29] The New York Times. (2019, 05 09). Stock Market Drop Extends to Fourth Day as U. S. Prepares to Raise China Tariffs. Retrieved June 21, 2019*, from The New York Times: https:/www.nytimes.com/2019/05/09/business/china-tariffsstock-market. html.

[30] The World Bank. (2019, April 01). The World Bank in Egypt. Retrieved June 20, 2019, from World Bank: 1. https://www.worldbank.org/en/country/egypt/overview\#1 2. https://www.worldbank.org/en/country/egypt/overview\#3.

[31] The World Bank/East African Community Secretariat. (2016). East African Common Market Scorecard 2016: Tracking EAC Compliance in the Movement of Capital, Services and Goods. Retrieved June 21, 2019, from East African Community: https://d3n8a8pro7vhmx.cloudfront.net/eatradehub/pages/289 3/attachments/original/1481012380/East-Africa-CommonMarket-Scorecard-2016.pdf?1481012380.

[32] Wama, M. (2014). The Dynamics and Fallout of East African Community Common Market: Trade Aspect and Citizens Rights. Greener Journal of Political and Socila Sciences, pp. 26-38.

[33] World Bank Group. (2018). Kenya Trade Statistics. Retrieved June 24, 2019, from World Integrated Trade Solution: https://wits.worldbank.org/CountryProfile/en/KEN\#.

[34] York, E. (2018). The Impact of Trade and Tariffs on the United States. Tax Foundation: Fiscal Fact No. 595, pp. 1-9.

[35] Zhang, T., \& Mathews, K. (2019). Assesing the Degree of Financial Integration in Asean-A perspective of banking competitiveness. Research in International Business and Finance, vol. 47 pp. 487-500.

[36] African Development Bank Group (nd). Eastern Africa Regional Integration Strategy Paper 2018-2022.

[37] The World Bank. (2018). Understanding Poverty. Regional Trade Agreements. Retrieved June 01, 2020, from World Bank: https://www.worldbank.org/en/topic/regionalintegration/brief/regional-trade-agreements. 